\title{
1 Environmental drivers of lesser weever stings on the northeast Atlantic coast (A
}

\section{Lanzada beach, Spain)}

3 Padin, X.A. ${ }^{1, *}$, Alonso-Fernández, A. ${ }^{1,2}$, Lijó, A. ${ }^{3}$, Otero, V. ${ }^{3}$ and Otero, J. ${ }^{1}$

$4 \quad{ }^{1}$ Instituto de Investigacións Mariñas (CSIC), Eduardo Cabello, 6, 36208, Vigo (Spain)

$5 \quad 2$ Asociación Ecoloxía Azul (Blue Ecology, BEC), Pontevedra (Spain)

$6{ }^{3}$ Unidade Marítima de Salvamento e Rescate da Agrupación de Voluntarios de 7 Protección Civil, 36980, O Grove (Spain)

9 * Corresponding author: X.A. Padin. E-mail address: padin@,iim.csic.es; Telf: $10+34986231930$

\section{ABSTRACT}

13 Many marine species, including anemones, snails, jellyfish, coral and fish, are

14 venomous to humans, causing serious injuries or even death. Most of these animals live 15 in warm, shallow waters, which increases the chances of an encounter with them. The 16 majority of these interactions with humans are accidental; however, it is not well known 17 under which circumstances (if any) these encounters are more likely to happen. A 18 smart-city initiative was launched for A Lanzada beach (NW Spain) in the summer of 19 2014. As part of this initiative, lifeguards collated data on all incidents occurring on the 20 beach, including weever fish stings. Additionally, a number of environmental 21 parameters were monitored. Using this unique information, statistical models were 22 developed to evaluate under which environmental conditions beach users would be 23 more likely to be stung by lesser weevers. The optimal model showed that stings were 24 more likely at the southern end of this $2.7 \mathrm{~km}$ long beach, pointing to differences in sediment composition along the beach as a key factor. Moreover, warmer sea water and 
26 higher air temperature increased the chances of being stung. Furthermore, stings

27 increased at low tide and decreased under strong meridional wind conditions. Finally,

28 the number of stings increased with beach occupation up to a levelling-off point. All

29 this suggests that a combination of fish behaviour and favourable climate conditions for

30 beachgoers increases the chances of suffering an accidental encounter with lesser

31 weever fish. Our results, based on basic environmental information, constitute a simple

32 tool that could be used to provide precautionary advice to beach users in order to avoid accidental encounters with lesser weever fish.

Keywords: beach, warning services, lesions, lesser weever, poisonous fish, fish sting, northeast Atlantic coast, A Lanzada beach.

\section{Introduction}

Tourism on the coastline of the Iberian Peninsula is of huge economic

40 importance due to the climate conditions on this coast and the increase in recreational

41 and sport-related services, which makes it one of the favourite tourist destinations in

42 Europe (Eurostat, http://ec.europa.eu/eurostat/web/tourism/data/main-tables). One of the inconveniences that tourists can find on the coast and, therefore, a threat to this industry is the potential presence of poisonous marine animals whose stings have a large impact on public health and leisure in coastal areas; for instance, jellyfish in the Mediterranean

46 Sea (Ghermandi et al., 2015).

The hazard of jellyfish is widely recognised and has attracted great attention from the marine research community. In recent years, many studies have suggested that jellyfish populations are increasing in some areas of the world as a consequence of a combination of several factors, such as overfishing, acidification and global warming 
51 (Richardson et al., 2009; Purcell et al., 2007, 2012, but see Condon et al., 2012), and

52 these booms might cause public health issues. For instance, the number of jellyfish stings along the Mediterranean coast increased by 50\% from 2010 to 2012, reaching a total of 118,346 people stung (Bordehore et al., 2016) that far exceeded previous estimations of $>14,000$ people receiving medical treatment on the south and east Spanish coasts in August 2006 (Pingree and Abend, 2006). This huge number of people affected is an increasing problem with important socioeconomic costs (Mills, 2001; Hay, 2006; Purcell et al., 2007; Canepa et al., 2014; de Donno et al., 2014; Nunes et al., 2015; Ghermandi et al., 2015). This has led to the development of various earlywarning systems, from remote-sensing observations and coastal circulation models to different in-situ observations designed to study jellyfish outbreaks (Bentlage et al., 2009; Bernard et al., 2011; Marambio et al., 2013). impact on public health of other poisonous marine taxa, such as the blue-ringed octopus (Hapalochlaena spp.), cone snails (Conus spp.) or certain species of fish (Fenner et al., 2004). The lack of ecological and ethological knowledge (Lewis, 1980; Tortonese, 1986) about weever fish is particularly surprising in view of the fact that they are among the most venomous specimens along the Atlantic European coast and are quite common on the coasts of the Iberian Peninsula (Vasconcelos, 2001; Prista et al., 2003). Even though weever fish stings are popularly known to users of certain Spanish beaches, only one scientific paper, to our knowledge, has dealt with weever fish stings, detailing 414 cases along the 164 kilometres of the southern Spanish coastline during the summer of 1999 (Portillo et al., 2008). Based on the poor attention received, the trouble generated by weever fish seems to be minor compared to that caused by jellyfish. However, this impact could be more acute on specific beaches; accordingly, improving our knowledge 
of the factors that might be related to the incidence of weever fish stings is important.

Recent data on lesser weever fish stings seen on A Lanzada beach (northwest of

Spain, Fig. 1) during the summer of 2014 suggested a potential impact on public health

and leisure on Spanish beaches that was significantly greater than thought, taking this unusual problem to the level of that caused by jellyfish. Consequently, our objective was to evaluate the factors that might have driven weever fish stings in a typical summer season. By gathering information on interventions by lifeguards and in-situ environmental data through a smart-city initiative, we aimed to improve beach management. Statistical modelling was used to understand to what extent oceanographic and meteorological conditions drove lesser weever stings to beach users. This unprecedented analysis could become an early-warning system based on environmental variables and designed to provide online precautionary information to beachgoers.

\section{Methods}

\subsection{Study site and its lifeguard service}

O Grove is a small coastal town located in southern Galicia (NW Spain, Fig. 1).

92 Its population was 10,851 in 2014 (Instituto Galego de Estatística, www.ige.eu), although the population usually triples during summer. O Grove is a former island that is connected with the mainland by an isthmus whose western side is a beach called A Lanzada that is, on average and at high tide, 2.7 kilometres long and 40 meters wide (Fig. 1). Its sedimentary morphology is primarily influenced by the topography of the

97 bottom regions and the incidence of wave energy, which is concentrated in the central and southern areas when the waves come from the northwest (Durán et al., 2001). The surface of the beach is composed of fine white sand, with quartz being the main component, whose grain increases in size towards the ends of the beach. At the southern 


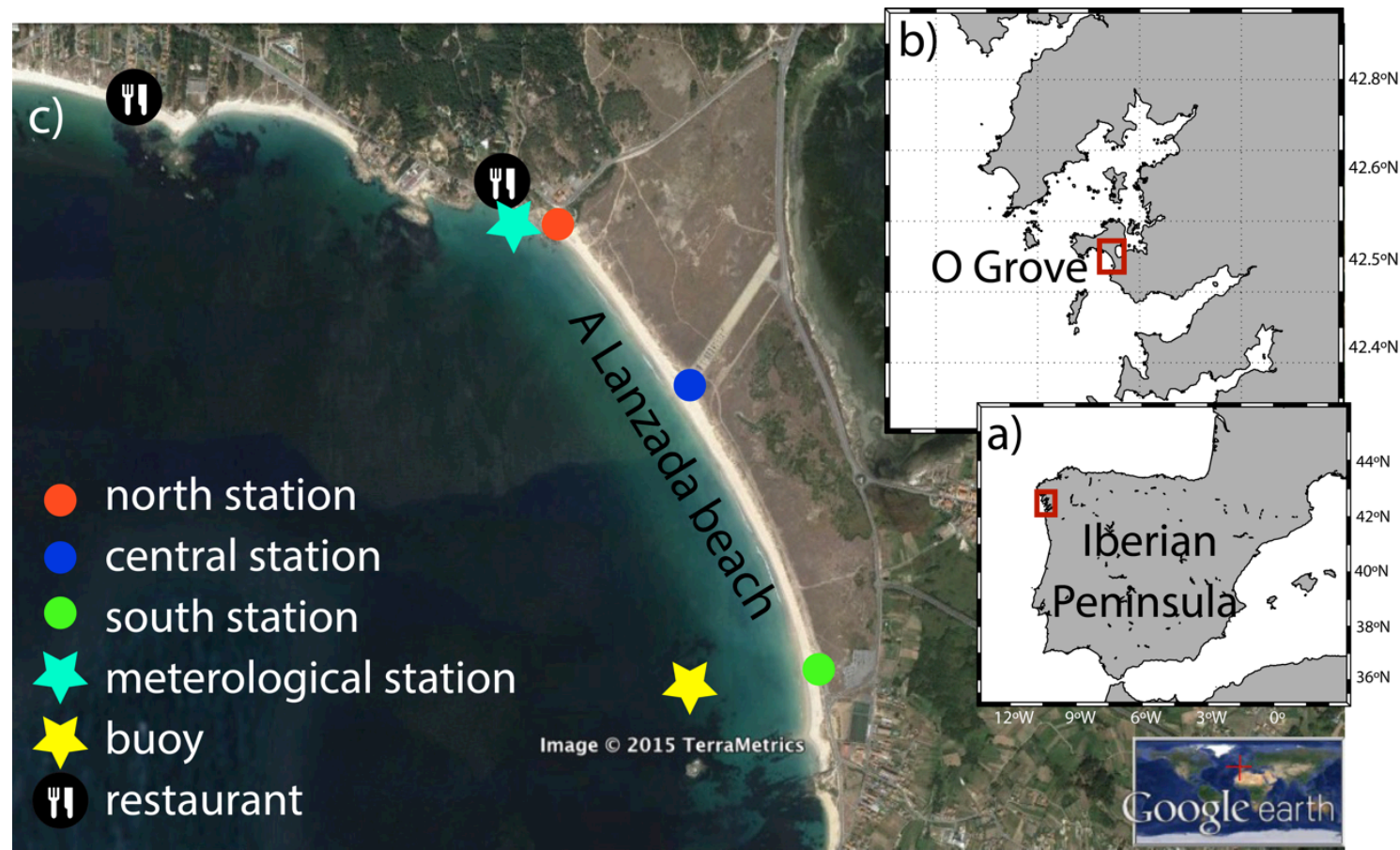

102

103 Fig. 1. Location of A Lanzada beach (NW Spain) and position of the lifeguard stations,

104 the meteorological station, the buoy and the restaurants.

105

106

107

108

109

110

111

112

113

114

115

116 
117 end, the grain size is larger and of biogenic origin. This is also an area of the beach

118 where a field of ripples and a shallow rocky outcrop are seen (Durán et al., 2001). The

119 tide in this area of the Spanish coast is semi-diurnal, with a range of 2.5 meters on

120 average, generating tidal currents that are practically negligible on this beach.

121 A Lanzada is used by large numbers of local people and tourists and has a

122 maximum capacity of roughly 12,000 people. In addition to its popularity among

123 beachgoers, A Lanzada beach was one of the first beaches in Spain to be awarded

124 different distinctions for water quality and environmental management, such as the Blue

125 Flag (http://www.blueflag.global/), in the last decades. During the summer season, first-

126 aid, surveillance and lifeguard services are provided daily from 11:00 to 20:00, local

127 time, by the $\mathrm{O}$ Grove Maritime Search and Rescue Unit (Unidade Marítima de

128 Salvamento e Rescate, UMSR), based in three lifeguard stations located in the north,

129 centre and south of the beach (Fig. 1). These locations follow the distribution of

130 beachgoers, with each zone concentrating approximately $20 \%, 50 \%$ and $30 \%$ of the

131 users of A Lanzada beach from north to south, respectively, according to the UMSR

132 team.

133

134 2.2. The lesser weever fish and its stings

135 The weever fish occurs from the northeastern Atlantic to Morocco and

136 throughout the Mediterranean Sea (Lewis, 1980; Tortonese, 1986). The two main

137 species occurring on the Galician coast are the greater weever (Trachinus draco

138 Linnaeus, 1758) and the lesser weever (Echiichthys vipera Cuvier, 1829). These species

139 have significantly different bathymetric distributions. While the greater weever prefers

140 deeper offshore waters, the lesser weever inhabits shallow inshore waters from the low-

141 tide mark to a depth of 50 metres (Wheeler, 1978). Therefore, bathers are mainly stung 
142 by the lesser weever, while the greater weever is responsible for most of the stings 143 suffered by fishers and divers.

144 The lesser weever (Fig. S1) is a short, stout fish that can reach up to $150 \mathrm{~mm}$ in 145 standard length (Tortonese, 1986) and lacks a swim bladder (Jones and Marshall, 1953).

146 This considerable adaptation to a demersal habitat allows them to stay close to or lie on

147 the bottom, where water movement is strongly reduced. Lesser weevers move up the 148 beach with the tide, and down with the outgoing tide, even though some individuals 149 may remain buried in the sand during the low-tide period. In winter, as temperature

150 falls, lesser weevers also move into deeper waters, hibernating until the onset of warmer 151 weather (Heinke, 1913). The lesser weever displays nocturnal activity, lying buried 152 during the day and emerging to forage at night (Lewis, 1976; Wheeler, 1978). Its diet is essentially carnivore, with the lesser weever preying preferentially upon crustaceans 154 (Quiniou, 1978; Sorbe, 1981) and fish (Dauvin, 1988), and secondarily on polychaetes and bivalves (Collignon and Aloncle, 1960). Under threat, this fish responds by either moving deeper into the sand or rising

157 the venomous spines located on the first dorsal fin, which is totally black (Fig. S1). The 158 lesser weever is considered to be the most dangerous of European weevers due to its 159 poison and its frequent occurrence at beaches (Tortonese, 1986). The dorsal spines and 160 a single spine on each main gill cover contain venomous thermolabile proteins (Davies 161 and Evans, 1996). The most common symptoms when bathers suffer a sting are a sharp 162 stab as the spine penetrates the skin, followed by pain shortly afterwards which begins 163 in the site of the puncture and expands around it, usually affecting the whole foot. The 164 victim may also experience itching, minor swelling, irritation, dizziness and even 165 fainting. Headache, nausea, vomiting, sweating, and syncope may occur rarely (Cain, 166 1983; Fener, 2004; Portillo-Strempel et al., 2009; Duran and Duran, 2014). 

thermolabile, immersion in hot water should be applied (Gweta et al., 2008; Lopacinski et al., 2009). Other treatments include the application of warmed stale urine to the wound and even prophylactic antibiotics to avoid the possibility of infection (Cain,

171 1983; Fener, 2004; Portillo-Strempel et al., 2009; Duran and Duran, 2014). As a 172 commercial antiserum is not available (Cain 1983; Mayser et al., 2003), basically empirical treatment (Mayser et al., 2003) is usually sufficient for pain relief, even though severe cases might require specific treatment (Maretic et al., 1973; Linares del Río et al., 1989; Williamson et al., 1996). In particular, the protocol followed by the O

176 Grove UMSR service consists of the following four steps: 1) locate the sting and wash

177 with diluted ammonia while checking that no part of the spine remains inside; 2) put the 178 affected foot or body part into hot water; 3) apply some antihistamine cream and cover with bandage, and 4) walk on a hot area.

\subsection{Data sources}

During the summer of 2014, the O Grove UMSR decided to carry out an experiment implementing new technologies as coastal management tools, namely a specific web application designed to digitalise every event (e.g., accidents, requests for materials, different types of care given to bathers), services provided in the lifeguard stations, including health care after lesser weever fish stings, and a smart-city initiative

187 that temporarily provided online real-time meteorological and oceanographic

188 information for A Lanzada beach during that summer. The web application installed on tablets located in each lifeguard station was used to record the daily number of lesser weever fish stings attended to in the three different lifeguard stations along the beach 
192 or inert objects because of the particular symptoms of these fish stings and the

193 lifeguards' expertise.

194 Environmental information for the study area was transmitted online through a

195 website and gathered by a monitoring system formed by a buoy and a meteorological

196 station. The buoy, designed by Marine Instruments (www.marineinstruments.com) for

197 being used near the coastline, was discreetly moored as part of a set of barrage buoys

198 (Fig. 1). This float measured wave height continuously by means of accelerometers and

199 water temperature at a depth of $10 \mathrm{~cm}$ using an industrial thermometer with resolutions

200 of $0.1 \mathrm{~m}$ and $0.2^{\circ} \mathrm{C}$. Values were transmitted every 10 minutes by a GPRS system. A

201 professional weather station (Oregon Scientific model WMR200) recorded

202 meteorological parameters from wind, temperature, humidity and ultraviolet radiation

203 sensors and a self-emptying rain gauge with a frequency of every 5 minutes (Fig. 1).

204 Therefore, meteorological and oceanographic information was obtained for a single

205 location at the beach that we consider representative of the entire beach in view of the

206 length of the study area. The dataset was completed with ocean tide height estimated

207 using the software IOS Tidal Package, developed by the Institute of Ocean Sciences,

208 Canada. In order to have the same temporal frequency that daily lesser weever fish

209 stings, environmental data were recorded during the open hours of the lifeguard

210 stations, that is, from 11:00 local time to 20:00 local time, and averaged daily.

211 As the number of users of the beach was not available, the daily number of

212 customers of two nearby restaurants was used as a proxy for beach occupation (Fig. 1).

213 More specifically, both restaurants provided information on the number of customers at

214 lunch time each day during the summer season. The data from both restaurants were

215 highly related (Fig. S2); accordingly, we used the number of costumers of the closest

216 restaurant as an indicator of daily beach users during the whole study period. We 
217 assumed that $100 \%$ beach occupation corresponded with the maximum number of

218 clients in the restaurant, which coincided, in both cases, with the $16^{\text {th }}$ of August, while

219 the occupation for the other days was estimated as a proportion of people in relation to

220 the maximum. Given that the theoretical maximum capacity of the beach is 12,000

221 people per day, we estimated the daily number of beach users relative to that maximum.

222 Furthermore, users are not evenly distributed along the beach, as mentioned above;

223 consequently, we assumed that on a given day $20 \%$ of beach users were located in the

224 northern part of the beach and $50 \%$ in the centre, while $30 \%$ of the users of A Lanzada

225 stayed at the southern end of the beach.

\subsection{Data analysis}

We modelled the sting rates using generalised linear models (GLMs) with a negative binomial distribution and a log link function. The stings were highly skewed, with many days having zero stings, one and two stings recorded on a few days, and so on (Fig. 2). Therefore, the observed stings $S$ on day $i$ were assumed to follow a negative binomial distribution with a mean $\mu_{i}$ and variance $\mu_{i}+\mu_{i}^{2} / k$, where $k$ is the dispersion parameter. The negative binomial distribution is appropriate for overdispersed data like this, where the variance is larger than the mean.

The optimal model was selected using a backward model selection procedure based on the Akaike Information Criteria (AIC). We started with a full model which included all spatial and environmental variables that could potentially drive sting rates; accordingly, the expected mean number of stings $\mu$ on a day $i$ can be formulated as follows:

$$
\log \left(\mu_{i}\right)=\alpha+\beta_{1} \mathrm{LS}_{i}+\beta_{2} \mathrm{BO}_{\mathrm{i}}+\beta_{3} \mathrm{BO}_{i}^{2}+\beta_{4} \mathrm{SST}_{\mathrm{i}}+\beta_{5} \mathrm{AT}_{i}+\beta_{6} \mathrm{TH}_{i}+\beta_{7} \mathrm{WH}_{\mathrm{i}}+\beta_{8} \mathrm{~V}_{\mathrm{i}}
$$


244 where $\alpha$ is an intercept, $\beta_{\mathrm{n}}$ are the coefficients of the linear terms, and $\varepsilon_{i}$ is a vector of 245 residuals assumed to be independent. Covariates were defined as follows: LS is the 246 lifeguard station, BO is beach occupation, SST is the mean sea surface temperature 247 during the lifeguards' working hours, AT is the mean air temperature during the 248 lifeguards' working hours, TH is the mean tide height during the lifeguards' working 249 hours, $\mathrm{WH}$ is the mean wave height, and $\mathrm{V}$ is the speed of the meridional wind component. Before model fitting, variance inflation factors (VIFs) were calculated to detect collinearity issues (Zuur et al., 2007). The calculation of VIFs revealed no signs of collinearity among the explanatory variables, with all values below a cut-off level of 3. Finally, each model coefficient was transformed to percentage change in the number 254 of stings for ease of interpretation using the formula $\left(\exp ^{(\beta)}-1\right) \times 100$. Model residuals were inspected for model misspecification or any remaining structure not accounted for in the above equation. All analyses and the treatment of the data were performed with $\mathrm{R}$ language version R-3.4.3 (R Development Core Team, 2017) and using the MASS_7.347 package (Venables and Ripley, 2002).

\section{Results}

\subsection{Environmental conditions}

During the study period, winds with a northerly component prevailed at A

263 Lanzada beach from the $1^{\text {st }}$ of July to the $13^{\text {th }}$ of September 2014 (Fig. 2). This general 264 dominance was interrupted by short events of southwesterly winds (Fig. 2c), especially 265 between the $1^{\text {st }}$ and the $13^{\text {th }}$ of August and when sea surface temperature reached 266 maximum values (around $21^{\circ} \mathrm{C}$ ) (Fig. 2b). Sea surface temperature showed large 267 oscillations throughout the summer, with pulses of warm waters under the influence of 


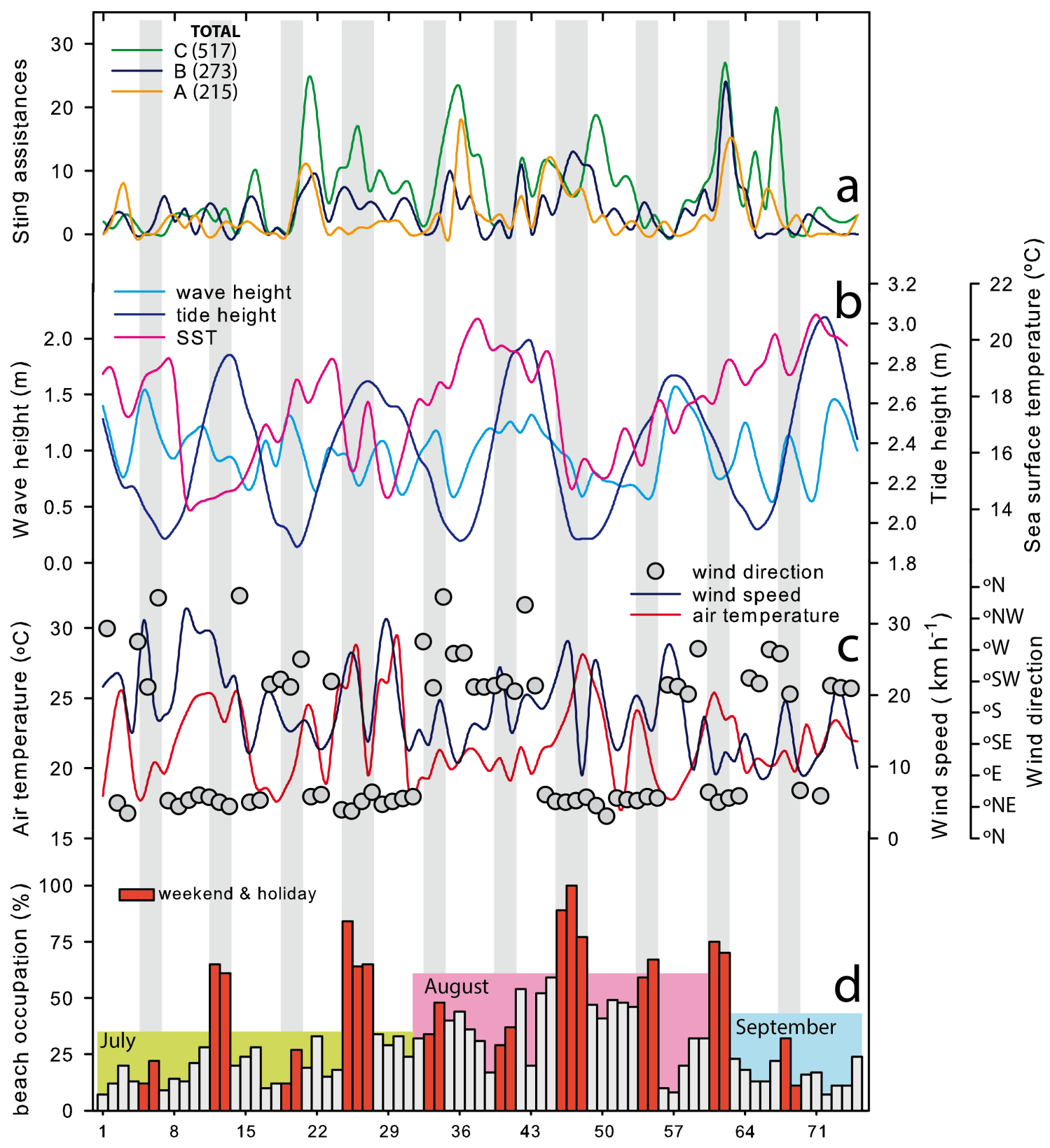

Number of days from July $1^{\text {st }}$

270 Fig. 2. Daily records of medical care provided for lesser weever fish stings, fluctuations

271 in meteorological and oceanographic conditions at the beach, and percentage of beach

272 occupation during the summer of 2014. 
southwesterly winds and cooling events under north wind regimes; the coldest day

277 recorded was the $10^{\text {th }}$ of July, with an average value of $14.1^{\circ} \mathrm{C}$ (Fig. 2b). On those days,

278 northerly winds were the most intense, reaching $32 \mathrm{~km} \cdot \mathrm{h}^{-1}$ (Fig. 2c). However, they

279 did not cause the highest waves due to the orientation of the beach; instead, such waves

280 were seen under the influence of southwesterly winds, with a daily average value of 1.6

$281 \mathrm{~m}($ Fig. 2b).

282

\subsection{Lesser weever fish stings}

The staff of the three lifeguard stations of A Lanzada beach provided medical care to a total of 1,005 cases of lesser weever fish stings during the summer of 2014 (Fig. 2a). This figure represents $0.3 \%$ of all the people who visited the beach during that summer. A significantly higher incidence of stings was recorded in the southern lifeguard station, where 517 people were attended to, whereas the cases in the centre and at the north end of the beach were almost a half of that figure in both stations, namely 273 and 215 stings, respectively. The stings followed a similar temporal

291 distribution regardless of the station (Fig. 2a). The maximum daily occurrence of lesser

292 weever fish stings was seen in the southern station, with 27 interventions on the $31^{\text {st }}$ of

293 August. On the same date, a maximum of 24 stings was also recorded in the central

294 area. Although the number of weever fish stings at the northern end of the beach was

295 also high on that day, a maximum of 18 people stung was reached on the $5^{\text {th }}$ of August.

296 The number of medical interventions due to stings during maximum occupancy of the

297 beach was 8 in the northern and central medical stations, and 9 interventions in the 298 southern station. 
302 AT, TH, and V as explanatory variables (Table 1). The probability of suffering a lesser

303 Table 1. Summary table of model parameters for the most optimal model for the daily

304 number of lesser weever fish stings at the A Lanzada beach in summer 2014. S.E.:

305 standard error. $\mathrm{N}=225$, Dev. Expl. $=45.5 \%$.

306

\begin{tabular}{ccccc}
\hline \hline Parameter & Estimate & S.E. & z-value & p-value \\
\hline \hline Intercept & -2.43 & 1.09 & -2.2408 & 0.0250 \\
\hline LS (B) & 6.30 & 1.07 & 5.8821 & $<0.0001$ \\
\hline LS (C) & -1.84 & 0.84 & -2.2005 & 0.0278 \\
\hline BO & -0.27 & 0.18 & -1.5411 & 0.1233 \\
\hline BO & 0.74 & 0.15 & 5.0567 & $<0.0001$ \\
\hline SST & 0.19 & 0.04 & 4.6402 & $<0.0001$ \\
\hline AT & 0.11 & 0.03 & 4.1329 & 0.0000 \\
\hline TH & -0.010 & 0.002 & -5.3842 & $<0.0001$ \\
\hline V & -4.41 & 1.29 & -3.4076 & 0.0007 \\
\hline $\mathbf{V}^{2}$ & -3.87 & 1.07 & -3.6149 & 0.0003 \\
\hline
\end{tabular}

307

308 
weever fish sting varied significantly depending on the location at the beach, with the south part of A Lanzada being the zone that showed the highest probability of an injury (Table 1 and Fig. 3a). Relative to the north part of the beach, the chances of being stung were $23 \%$ lower in the middle part, while the chances of being injured were $108 \%$ higher in the southern part. Beach occupation showed a non-linear relationship with the number of stings (Table 1) which increased linearly with the number of people and levelled off at around 4,000 people (Fig. 3b). Both sea surface temperature (Fig. 3c) and air temperature (Fig. 3d) were positively related to the number of stings (Table 1). A rise of $1{ }^{\circ} \mathrm{C}$ in sea water temperature increased the number of stings by $20.2 \%$ (from $10.2 \%$ to $31 \%$ C.I.) in all locations, while an increment of $1{ }^{\circ} \mathrm{C}$ in air temperature resulted in an $11.1 \%$ (from $5.4 \%$ to $17.2 \%$ C.I.) increase in weever fish stings in all zones. Additionally, low-tide situations were significantly more favourable for fish stings (Table 1 and Fig. 3e), revealing 1\% fewer stings by each additional centimetre of mean tide height (from -1.4 to $-0.7 \%$ C.I.). Furthermore, the $\mathrm{V}$ showed a non-linear relationship with weever fish stings, with the maximum number of stings occurring at around $-6 \mathrm{~km} \cdot \mathrm{h}^{-1}$, and showing a rapid decrease with more intense upwelling conditions (Table 1 and Fig. 3f). Finally, normalised residuals did not show any departure from normality, any sign of heterogeneity or any remaining misspecification issues (Fig. S3).

\section{Discussion}

Envenomation caused by stings of marine creatures is a common hazard for humans that might have important health and social implications. Most serious injuries are considered to occur in the temperate or tropical waters of the Indo-Pacific region, although cases of marine envenomation have been described in multiple other regions 

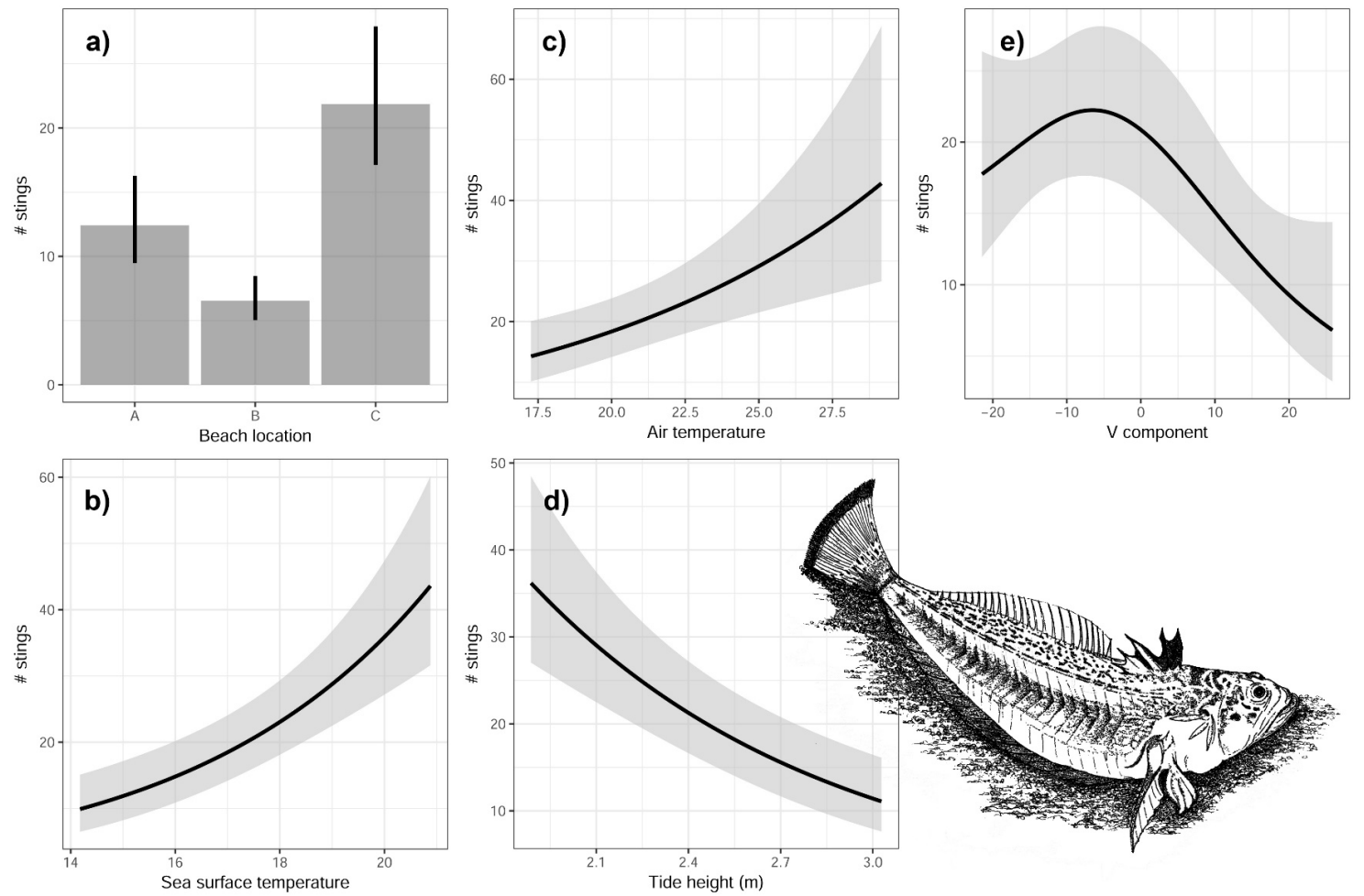

Fig 3. Model output assuming a number of 1,000 beach users and fixing the rest of the parameters at their mean values. Predicted number of stings for each beach zone (a) and relationships with sea surface temperature $\left({ }^{\circ} \mathrm{C}\right)(\mathrm{b})$, air temperature $\left({ }^{\circ} \mathrm{C}\right)(\mathrm{c})$, tide height (m) (d) and meridional wind component (d) and side view of lesser weever fish. 
of the world (Williamson et al., 1996). Among venomous sea creatures, jellyfish and other cnidarians have aroused great public concern and scientific interest in recent decades because of the postulated increase in blooming of these species due to anthropogenic disturbance and climate changes (e.g., Dong et al., 2010). However, research on other poisonous taxa is much more scant, and the factors that might determine the pattern of incidents and encounters with these animals are hardly known.

The weever fish is among the most venomous marine fishes, although encounters with this fish have been considered unusual and injuries are assumed to be relatively rare (e.g., British Isles, Cain, 1983). On the southern Spanish coast, however, Portillo-Strempel et al. (2009) reported 15 fish stings per 100,000 inhabitants, considering this rate as a non-negligible risk. In spite of this, detailed studies exploring the factors that may drive the rates of weever fish stings are lacking. At A Lanzada beach, we found an average rate of 4.12 stings per 1,000 people, ranging from 0 to 35.5 stings. This suggests that such an extraordinary value and the considerable fluctuations during summertime may be caused by fish behaviour and favourable weather for bathing.

Presumably, the rate of stings should be greater when more people bathe, as suggested for the south coast of Britain in comparison with the north (Cain, 1983). We found that the number of stings at A Lanzada increased linearly with beach occupation up to a value of around 4,000 people, at which point this relationship levelled off. Unfortunately, detailed information on beach occupation per day and beach zone was not available; therefore, our occupation index was built using data on customers of a nearby restaurant and assuming a specific distribution of beach users along the beach. The use of this proxy might have implications for the final model results (e.g., size effects); however, we believe that the shape of lesser weever stings in the statistical 
model, regardless of the used beach occupation index, would be limited by fish abundance. Nonetheless, we are aware that data on beach occupation should be improved and more accurate.

The concentration of medical interventions by lifeguards varied spatially along the beach, with the south station of A Lanzada attending to half of the injured despite covering $30 \%$ of users. Moreover, the number of stings was significantly lower in the central zone, where $50 \%$ of beach users are located. Environmental monitoring at a single point of the beach did not allow us to interpret this spatial variability. In view of the small area studied and the fair summer weather, we can speculate that the differences in medical interventions in the three stations may be related to beach morphology, sedimentology and/or current dynamics. In this regard, the southern end of the beach is characterized by having a field of ripples of biogenic origin and large grain size as well a shallow rocky outcrop close by, while fine-grain quartz dominates in the other areas of the beach (Durán et al., 2001). Therefore, weever fish might have a preference for coarser sediments, resulting in greater abundance of fish in these habitats. The presence of sand banks might also play a substantial role (Ellis et al., 2007). Furthermore, a non-homogeneous distribution of the availability of prey on the feeding grounds might explain the variability along the beach as well (Braber and de Groot, 1973; Dexter, 1984).

Good weather conditions seem to influence the rate of stings, as indicated by the direct correlation with sea surface temperature and air temperature. These relationships suggest that more benign weather conditions would lead beach users to bathe more, thus raising the probability of a sting. In spite of the fact that higher temperatures would determine beachgoers' behaviour primarily, we cannot exclude the possibility that warmer waters might also affect the behaviour of this species of fish. Indeed, it is well 
known that temperature controls the ecology of lesser weevers, since they initiate a hibernation process as waters cool down in the winter period (Heinke, 1913). Furthermore, an increase in their populations has been seen which is related to warming conditions in the Bay of Biscay (Parmesan and Yohe, 2003) and the North Sea (Beare et al., 2004; Perry et al., 2005). As in those regions, Galician waters are also undergoing an interannual warming process (Pérez et al., 2010); however, the lack of reliable time series on lesser weever abundance (or on their stings as a proxy for abundance) prevents a thorough analysis of long-term trends.

Both beachgoers' and fish behaviour and distribution might also explain the relationship between tide height and the number of stings. The tidal range seen with the slope of the beach expands the area accessible to beachgoers and also increases the probability of stepping on lesser weevers when they are buried in the sand. In this region, the tide has a semidiurnal cycle, with primarily a period of around 12 hours and 25 minutes. As a result, there are days when a low tide coincides with a maximum influx of beachgoers at around 16:00 local time and maximises the intertidal area accessible to users. This situation where the number of stings is expected to be high coincides, due to tidal periodicity, with a high tide towards the sunrise. At this time, lesser weevers are buried in the sand after their nocturnal activity; consequently, they are more likely to move into the intertidal zone at high tide (Lewis, 1976). Therefore, the areas on which beach users step and those in which lesser weevers are buried will be coincident (separated) at low (high) tide in the first hours of the afternoon.

Galician waters, as northern boundary of the Iberian-Canary current upwelling system, are a highly productive ecosystem (Longhurst, 1995; Aristegui et al., 2009). Northerly winds that promote coastal upwelling (Pardo et al., 2011) at these latitudes prevailed at A Lanzada beach during the summer of 2014. The dominance of upwelling- 
favourable winds caused the displacement of surface waters along this coast and the consequent upward replacement with cold, nutrient-rich waters. The reverse process, called downwelling, when southerly winds pile up warm surface water towards the coastline, took place in successive pulses. The fluctuations of the meridional wind speed component and the variability of lesser weever fish stings showed a dome-shaped relationship, with a maximum being attained at mild north winds of $-6 \mathrm{~km} \cdot \mathrm{h}^{-1}$, that is, under moderate coastal upwelling conditions. In addition to replacing warm surface water with cool subsurface water, upwelling events also have a potential impact on the fish community fertilising the coastal waters or modifying the coastal currents (ÁlvarezSalgado et al., 2009). The change in wind direction to south winds generates a remarkable fall in the number of interventions on the beach, while a lower reduction rate is seen under an intensification of north winds. The coinciding reduction in stings under an intensification of wind speed, regardless of wind direction, could be related to the generation of waves. The limited ability of lesser weevers to face the dragging of the waves due to their lack of a swim bladder makes these fish move away from the surf zone under the action of higher waves. In fact, waves exceeding 1.5 meters reduced the values of people stung to almost zero. The orientation of the beach, much more protected from north winds than from other winds, could explain the impact of the direction of the meridional wind component on the number of lesser weever stings.

The uniqueness of the database analysed here, showing 1,005 people stung by lesser weever fish at a $2.7 \mathrm{~km}$ beach during the summer of 2014 , does not allow us to compare our findings with the events seen at other summer times at the same beach or other beaches. However, information from other sources pointed out at the summer of 2014 as a year when many interventions were required. For instance, information published in local newspapers reported 9,230 interventions attributed to lesser weever 
fish stings along the $30 \mathrm{~km}$ coastline of the municipality of Vigo (Galicia, Spain) during the same season. Those beaches and A Lanzada beach, separated by 75 kilometres, are located within the Rías Baixas, four coastal embayments between $42^{\circ} \mathrm{N}$ and $43^{\circ} \mathrm{N}$ of NW. A gross extrapolation of these values along the $\sim 500 \mathrm{~km}$ of littoral of the Rías Baixas would result in an estimation close to 100,000 people stung by lesser weevers. The magnitude of this figure exceeds the numbers reported for other Spanish zones (Portillo-Strempel et al., 2009) and elsewhere in Europe (Cain, 1983), and it would be even higher than the well-known cases of jellyfish stings seen, for example, in the Mediterranean Sea (Bordehore et al., 2016).

The empirical model described in this study was able to explain $\sim 45 \%$ of the lesser weever fish stings attended to on A Lanzada beach (NW Spain) during the summer of 2014. Model performance could be improved by recording the time when the sting occurs and incorporating into the analysis a better beach occupation index measured in situ. This would facilitate a better understanding of the sting dynamics which would be the result of complex interactions between fish and human behaviour with the environment. In any case, the present work shows that basic information gathered by lifeguards and complemented with data on local environmental conditions can be successfully used to evaluate the incidence of weever fish stings. Empirical models at a local scale, such as the one developed here for A Lanzada beach, bring about the possibility of providing public, real-time information to forecast the probability of lesser weever fish stings and minimise the risk for beachgoers. Additionally, these models would help to optimise the working time of lifeguards, who spend at least 30 minutes on each person attended to, with such provision of services representing $90 \%$ of all interventions by the lifeguard services. Furthermore, the in-situ collection of information on beaches that is useful and accessible for the scientific 
community could be the basis for evaluating large-scale spatio-temporal trends and proposing management measures.

\section{CONCLUSIONS}

This database opportunely compiled using information gathered on A Lanzada beach through a smart-city initiative during the summer of 2014 indicates that lesser weever stings are a more common problem than reported by the literature to date. On a $2.7 \mathrm{~km}$ beach, a total of 1,005 stings were recorded in three lifeguard stations from the $1^{\text {st }}$ of July to the $13^{\text {th }}$ of September. The provision of medical care was not homogeneous along the entire beach; instead, it was required especially at the southern end (517 cases), while it was needed less frequently in the central area (215 cases). The incidence described for A Lanzada beach using publicly released information suggests that the incidence of lesser weever stings along the northwestern Spanish coast is at least comparable to the incidence of jellyfish stings on the Mediterranean coast.

In addition to the characteristics of the beach (orientation, morphology, etc.), environmental conditions correlated with the number of people stung, which explains almost a half of the lesser weever stings (45\%) out of the total variability. Sea surface temperature and air temperature showed a direct relationship with the interventions on the beach, while the correlation with tide height and a northerly wind component constituted an inverse association and a dome-shaped association, respectively. Besides relating to bathers' behaviour on the beach, our results seem to indicate the importance of the spatio-temporal dynamics of lesser weever populations for the total number of stings. It also seems clear that there is a need to improve the studies on the ecology of this little-known fish, especially in response to a potential increase in the populations on the Atlantic European coast. 
The coincidence between the habitat of this little-known poisonous marine fish, an important tourist industry and the concentration of population on the coast will have a socioeconomic impact. Based on these results, an appropriate beach monitoring system and new technologies similar to those used on A Lanzada beach would provide information for the prevention of lesser weever stings.

\section{Acknowledgements}

We express our gratitude to the group of lifeguards on the beach of A Lanzada in O Grove for their great work and meticulousness in collecting the data. We want to especially thank the restaurants Merendero A Terraza and Arrocería A Lanzada for providing information on the number of their clients. The drawing of a lesser weever

was kindly provided by the artist Gerardo Fernández Carrera (gerardofcarrera@gmail.com).

\section{References}

Álvarez-Salgado, X.A., Borges, A.V., Figueiras, F.G., Chou, L., 2009. Iberian margin: the Rías. In: Liu, K.-K., Atkinson, L., Quiñones, R., Talaue-McManus, L. (Eds.), Carbon and Nutrient Fluxes in Continental Margins: A Global Synthesis. SpringerVerlag, New York.

Arístegui, J., Barton, E.D., Álvarez-Salgado, X.A., Santos, A.M.P., Figueiras, F.G., Kifani, S., Hernández-León, S., Mason, E., Machú, E., Demarq, H., 2009. Subregional ecosystem variability in the Canary Current upwelling. Prog. Oceanog. 83, $33-48$.

Beare, D.J., Burns, F., Greig, A., Jones, E.G., Peach, K., Kienzle, M., McKenzie, E., Reid, D.G., 2004. Long-term increases in prevalence of North Sea fishes having southern biogeographic affinities. Mar. Ecol. Prog. Ser. 284, 269-278. 
Bédry, 1997. Epidemiologie des envenimations marines sur le litoral atlantique. Infotox - Bull. Soc. Tox. Clin. 1, $3-7$.

Bédry, R., Pillet, O., Rivet, P., Ha, D., Favarel-Garrigues, J.C., 1998. Epidemiologie des agressions par animaux venimeux marins sur le littoral Atlantique sud pendant la période estivale 1996. Réanimation Urgences 4, 375-80.

Bentlage, B., Peterson, A.T., Cartwright, P., 2009. Inferring distributions of chirodropid box-jellyfishes (Cnidaria: Cubozoa) in geographic and ecological space using ecological niche modeling. Mar. Ecol. Prog. Ser. 384, 121-133.

Bernard, P., Berline, L. and Gorsky, G., 2011. Long term (1981-2008) monitoring of the jellyfish Pelagia noctiluca (Cnidaria, Scyphozoa) on Mediterranean coasts (Principality of Monaco and French Riviera). J. Oceanog. Res. Data 4, 1-10.

Braber, L., De Groot, S.J., 1973. The food of five flatfish species (Pleuronectiformes) in the southern North Sea. Neth. J. Sea Res. 6, 163-172.

Bordehore, C., Alonso, C., Sánchez-Fernández, L., Canepa, A., Acevedo, M., Nogué, S. and Fuentes, V.L., 2016. Lifeguard assistance at Spanish Mediterranean beaches: Jellyfish prevail and proposals for improving risk management. Ocean Coast. Manag. 131, 45-52.

Cain, D., 1983. Weever fish sting: an unusual problem. Br. Med. J. 287, 406-407.

Canepa, A., Fuentes, V., Sabatés, A., Piraino, S., Boero, F., Gili, J.M., 2014. Pelagia noctiluca in the Mediterranean Sea. In: Pitt K., Lucas C. (eds) Jellyfish Blooms. Springer, Dordrecht.

Collignon, J., Aloncle, H., 1960. Le régime alimentaire de quelques poissons benthiques des côtes marocaines. Bull. Inst. Pêches Marit. Maroc. 5, 17-29.

Condon, R.H. et al., 2012. Questioning the rise of gelatinous zooplankton in the world's oceans. BioScience 62, 160-169. 
Davies, R.S., Evans, R.J., 1996. Weever fish stings: a report of two cases presenting to an accident and emergency department. J. Accid. Emerg. Med. 13, 139-141.

Dauvin, J.C., 1988. Rôle du macrobenthos dans l'alimentation des Poissons démersaux vivant sur les fonds de sédiments fins de la Manche occidentale. Cah. Biol. Mar. 29, $445-467$.

De Donno, A., Idolo, A., Bagordo, F., et al., 2014. Impact of stinging jellyfish proliferations along south Italian Coasts: Human health hazards, treatment and social costs. Int. J. Environ. Res. Public Health, 11: 2488-2503.

Dexter, D.M., 1984. Temporal and spatial variability in the community structure of the fauna of four sandy beaches in south-eastern New South Wales. Aust. J. Mar. Fresh. Res. 35, 663-672.

Dong, Z., Liu, D., Keesing, J.K., 2010. Jellyfish blooms in China: dominant species, causes and consequences. Mar. Poll. Bull. 60, 954-963.

Duran, F.Y., Duran, O., 2014. Weever Fish Sting: An Unusual Problem. J. Acad. Emerg. Med. 13, 42-43.

Durán, R., Manso, F., Bernabeu, A., García-Gil, S., Vilas, F., 2001. Estudio de la dinámica sedimentaria de la plataforma interna gallega: La Lanzada (NO España). XIV Congreso Nacional de Sedimentología, Jaen (Spain). 10-16 de Septiembre.

Ellis, J.R., Maxwell, T., Schratzberger, M., Warr, K., Rogers, S.I., 2007. Small-scale heterogeneity in the mobile macro-epifauna associated with mud, sand and coarse habitats. ICES CM 2007/A:07, 17 pp.

Fenner, P.J., 2004. Venomous marine animals. SPUMS J. 34, 196-202.

Ghermandi, A., Galil, B., Gowdy, J., Nunes, P.A.L.D., 2015. Jellyfish outbreak impacts on recreation in Mediterranean Sea: welfare estimates from a socioeconomic pilot survey in Israel. Ecosyst. Ser. 11, 140-147. 
Gweta, S., Spanier, E., Bentur, Y., 2008. Venomous fish injuries along the Israeli Mediterranean coast: Scope and characterization. Isr. Med. Assoc. J. 10, 783-788.

Hay, S., 2006. Gelatinous bells may ring change in marine ecosystems. Curr. Biol. 16, $679-682$.

Heinke, F., 1913. Investigations on the plaice I. The plaice fishery and protective regulations. Rapp. P.-V. Réun. Cons. Perm. Int. Explor. Mer 17A, 1-153.

Jones, F.R.K., Marshall, N.B., 1953. The structure and function of the teleostean swim bladder. Bid. Rev. 28, 16-83.

Lewis, D.B., 1976. Studies of the biology of the lesser weever fish Trachinus vipera Cuvier. I. Adaptations to a benthic habit. J. Fish Biol. 8, 127-138.

Lewis, D.B., 1980. Studies on the biology of the lesser weever fish, Trachinus vipera Cuvier. II. Distribution. J. Fish Biol. 17, 127-133.

Linares del Río, F., Moiche García Pumarino, M., Herruezo Pérez, A., 1989. Aplicación terapéutica de los bloqueos anestésicos en las picaduras por araña de mar. Rev. Esp. Anestesiol. Reanim. 36, $57-59$.

Łopaciński, B., Bak, M., Fiszer, M., Czerniak, P., Krakowiak, A. 2009. Poisoning with weever fish venom: a case report. Przegl. Lek. 66, 464-465.

Hay, S., 2006. Marine ecology: gelatinous bells may ring change in marine ecosystems. Curr. Biol. 16, R679-R682.

Marambio, M., Nunes P.A.L.D., Fuentes, V., Blasco, D., Revke, I., 2013. Exploring the role of the social media platforms for providing public, real time information on jellyfish outbreaks: results from a worldwide première Iphone application in Catalonia, Spain. Abstract Fourth International Jellyfish Bloom Symposium, Hiroshima, Japan.

Maretic, Z., 1973. Some epidemiological, clinical and therapeutic aspects of 
envenomation by weeverfish sting. In: de Vries A, Kchva E, editores. Toxins of animals and plant origin. vol 3, London and New York, Gordon and Breach, p. $1055-1065$.

Mayser, P., Dreyer, F., Repp, H., 2003. Persistent skin reaction and Raynaud phenomenon after a sting by Echiichthys draco (greater weeverfish). Hautarzt 7, 633 $-637$.

Mills, C.E., 2001. Jellyfish blooms: are populations increasing globally in response to changing ocean conditions? Hydrobiologia 451, 55-68.

Nunes, P.A.L.D., Loureiro M.L., Piñol, L., Sastre, S., Voltaire, L., Canepa, A., 2015. Analyzing Beach Recreationists' Preferences for the Reduction of Jellyfish Blooms: Economic Results from a Stated-Choice Experiment in Catalonia, Spain. PLoS ONE $10, \mathrm{e} 0126681$.

Richardson, A.J., Bakun, A., Hays, G.C., Gibbons, M.J., 2009. The jellyfish joyride: causes, consequences and management responses to a more gelatinous future. Trend Ecol. Evol. 24, 312-322.

Pardo, P.C., Padin, X.A., Gilcoto, M., Farina-Busto, L., Pérez, F.F., 2011. Evolution of upwelling systems coupled to the long term variability of sea surface temperature and Ekman transport. Clim. Res. 48, 231 -246.

Parmesan, C., Yohe, G., 2003. A globally coherent fingerprint of climate change impacts across natural systems. Nature $421,37-42$.

Perry, R.I., Cury, P., Brander, K., Jennings, S., Möllmann, C., Planque, B., 2010. Sensitivity of marine systems to climate and fishing: concepts issues and management responses. J. Mar. Syst. 79, 427-435.

Pérez, F.F., Padín, X.A., Pazos, Y., Gilcoto, M., Cabanas, M., Pardo, P.C., Doval, M.D. and Farina-Bustos, L., 2010. Plankton response to weakening of the Iberian coastal 
upwelling. Glob. Change Biol. 16, 1258-1267.

Pingree, G., Abend, L., 2006. Spain's beaches and flora fell the heat. Available at http://www.csmonitor.com/2006/0914/p07s02-woeu.html

Portillo-Strempel, A., Herrera-Ceballos, E., Portillo-Strempel, J., 2009. Poisonous fish stings on the coast of Malaga, Spain: summertime incidence. Emergencias 21, 3235.

Prista, N.R., Vasconcelos, M.J., Costa, H.C., 2003. The demersal fish assemblage of the coastal area adjacent to the Tagus estuary (Portugal): relationships with environmental conditions. Oceanol. Acta 26, 525-536.

Purcell, J.E., Uye, S., Lo, W., 2007. Anthropogenic causes of jellyfish blooms and their direct consequences for humans: a review. Mar. Ecol. Prog. Ser. 350, 153-174.

Quiniou, L., 1978. Les poisons démersaux de la baie de Douarnenez. Alimentation et écologie. Thése 3e cycle, Océanogr. Biol., Univ. Brest, Brest, France, 222 p.

R Development Core Team, 2017. R: A Language and Environment for Statistical Computing. Ed. by R. F. f. S. Computing. R Foundation for Statistical Computing, Vienna, Austria.

Sorbe, J.C., 1981. Rôle du benthos dans le régime alimentaire des poissons demersaux du secteur Sud-Gascogne. Kieler Meeresforsch. Sonderh. 5, 479-489.

Tibballs, J., 2006. Australian venomous jellyfish, envenomation syndromes, toxins and therapy. Toxicon 48, 830-859.

Tortonese, E., 1986. Trachinidae. In: Fishes of the north-eastern Atlantic and the Mediterranean. P.J.P. Whitehead, M.L. Bauchot, J.C. Hureau, J. Nielsen and E. Tortonese (Eds), UNESCO, Chaucer Press, UK, pp. 951-954.

Vasconcelos, R., 2001. Composiçao e estrutura das comunidades ictíiticas dos estuários do Douro e Tejo. Thesis, Faculdade de Ciências da Universidade de Lisboa, Lisboa. 
Venables, W.N., Ripley, B.D., 2002. Modern applied statistics with S. Sringer.

Wheeler, A., 1978. Key to the fishes of northern Europe. Frederick Warne, London.

Williamson, J., Fenner, P., Burnett, J.W., 1996. Venomous and Poisonous Marine Animals: A Medical and Biological Handbook. University of New South Wales Press.

Weijerman, M., Lindeboom, H., Zuur, A.F., 2005. Regime shifts in marine ecosystems of the North Sea and Wadden Sea. Mar. Ecol. Prog. Ser. 298, 21-39.

Zuur, A.F., Leno, E.N., Smith, G.M., 2007. Analysing ecological data: Statistics for biology and health, Springer, New York. 672 pp. 